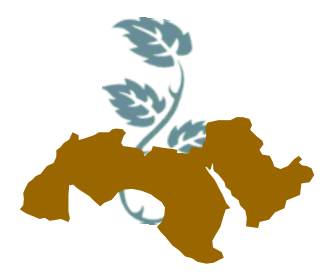

Arab Univ.

J. Agric. Sci., Ain Shams Univ., Cairo, 26(2), 621 - 632, 2018

\title{
EFFECT OF ROSEMARY EXTRACTS ON DIABETIC AND LIVER MALFUNCTIONAL RATS
}

\author{
Nada S.M. Elshaer ${ }^{1}$; K.M.A. Ramadan'; F.G. Moawad'; R.K. Attallah ${ }^{1}$ \\ and Hanan M.A. El-Ghandour ${ }^{2}$ \\ 1- Agricultural Biochemistry Dept., Fac. of Agric., Ain Shams Univ., Cairo, Egypt \\ 3- Biology lab. Regional Center for Food and Feed, Agricultural Research center, Giza, Egypt
}

Keywords: Carbon tetrachloride, Hyperglycemia, Liver toxicity, Rosemary, Streptozotocin

\section{ABSTRACT}

In this study, alcoholic and aqueous extracts of rosemary and its oil were used to investigate their effects on diabetic and liver malfunctional rats by administrating them with $\mathrm{STZ}$ or $\mathrm{CCl}_{4}$ for three weeks. The therapeutic effects of rosemary extracts (alcoholic and aqueous) and its oil against acute hyperglycemia induced by STZ in rats showed a decrease in the levels of fasting and postprandial blood glucose of rats treated with alcoholic extract of rosemary. In addition, results showed a restoration of these levels of the rats treated with aqueous extract or oil to their normal ranges after 3 weeks. There is a significant difference in lipid profile between rats treated with alcoholic or aqueous extracts and the negative control, where, the HDL in group administrated rosemary oil is significantly higher than both positive and negative control.

The protective effects of rosemary extracts (alcoholic and aqueous) and its oil against liver toxicity induced by $\mathrm{CCl}_{4}$ in rats showed a significant difference between both (negative and positive control) and the activity of AST and ALT in the rats treated by alcoholic and aqueous extracts of rosemary. The protective effects of the plant extracts against liver toxicant occurred by decreasing the activities of these enzymes. Oil rosemary had restored effect more than both ethanolic and aqueous extracts, but not significant. This protective effect occurred by decreasing the activities of AST, ALT and Alp enzymes. No significant $(p \leq 0.05)$ differences were noticed among the levels of serum total protein for all treatments compared to the negative and positive controls. The levels of total cholesterol and triglycerides recorded high values for the positive controls compared to the negative control. The protective effects of rosemary extracts against liver toxicant occurred by restoring the levels of these parameters to their normal values.

\section{INTRODUCTION}

There are several factors lead to liver toxicity and diabetes namely the toxins such as aflatoxins, drugs and chemicals such as heavy metals and organic solvents especially $\mathrm{CCl}_{4}$, streptozotocin (STZ) and alcohols.

There are many herbals which are used in therapeutic or protective effect against diseases in experimental animals. These herbals include rosemary and others.

Diabetes mellitus (DM) is a serious health problem being the third greatest cause of death all over the world, and if not treated, it is responsible for many complications affecting various organs in the body. Diabetes mellitus results in hyperglycemia and is characterized as type 1 in absolute insulin deficiency or type 2 in insulin resistance due to receptor insensitivity to endogenous insulin (EIHilaly et al 2007).

The main active constituent of Rosemary plant is the volatile oil which includes camphene, camphor, cineol, boroneol, resin, bitters matter, rosemary acid and flavonoids (Begum et al 2013).

The main constituents of rosemary oil are: camphor, 1,8-cineol, a-pinene, boroneol, camphene, $\beta$-pinene, limonene, verbenone, caryophylene and myrcene. The 1,8-cineol, boroneol and camphor compounds are presented with low quantity (Domokos et al 1997 and Salido et al 2003). 
Rosemary contains caffeic acid and rosmarinic acid, both of which are potent antioxidants as well as anti-inflammatory agents. Rosemary is also a good source of antioxidant vitamin E (alpha tocopherol) and other important antioxidants. In addition, rosemary contains 19 different chemical components with antibacterial action and volatile oil which reduce the airway constriction induced by histamine. The volatile oils in rosemary also reduce inflammation that contributes to liver and heart diseases. Herbalists think that rosemary may also help ease breast pain by acting as a natural drying agent to fluid filled cysts (Aruoma et al 1992 and Bakirel et al 2008).

Water-soluble extract from rosemary leaves is rich in rosemarinic acid (1.3\%) and flavonoids ( $3 \%)$. A wide range of oxygenated monoterpenes are identified: oxides, such as 1,8-cineole, and alcohols, such as borneol and $\alpha$-terpineol. Chemical composition of rosemary essential oil can vary between regions and it depends mostly on climate, soil composition, plant organ, age and stage of vegetative cycle (Faixova and Faix, 2008).

Effects of rosemary are attributed to the different chemical constituents including monoterpenes, diterpenes and the phenolic derivatives -mainly caffeic acid known as rosemarinic or carnosic acid and gallic acid. Among these bioactive constituents, the pharmacologic properties have been suggested to be highly attributed to rosemarinic acid, the predominant secondary metabolite in rosemary. Biochemically, rosemarinic acid is an ester of caffeic acid, hydroxydihydrocaffeic acid, chlorogenic acid and their hydrolyzed metabolites (El-Deeb, 1993; Rababah et al 2004; Wang et al 2004 and Herrero et al 2010). Rosemarinic acid has been suggested to have anti-atherogenic activity by preventing the oxidation (Hadafi et al 1998; Shetty, 2007; Dubois et al 2008; Park et al 2008; Vanithadevi and Anuradha 2008; Furtado et al 2010 and Moon et al 2010).

Rosemary contains a mixture of natural antioxidants. Generally, antioxidants dramatically change metabolism of glucose, lipid and proteins associated with cardiac diseases, (Fuhrman et al 2000). Antioxidants are found to perform several cardio protective properties including the ability to prevent LDL from oxidative modification by monitoring the levels of triglycerides, HDL and LDL. HDL (Nofer et al 2002) or accumulation of lipid peroxides on LDL (Mackness et al 1993). More or less, rosemary may exert antioxidant effects indirectly by increasing levels of antioxidants agents such as glutathione reductase, vitamin $C$ and $\beta$ carotene (Labban et al 2014).

Free radicals/reactive oxygen species are associated with many biological phenomena, such as inflammation, aging, and carcinogenesis. The antioxidant activity of polar extracts of rosemary is related to the content of phenolic compounds (i.e. carnosol, carnosic acid). Constituents in rosemary have shown a variety of pharmacological activities for cancer chemoprevention and therapy in in vitro and in vivo models (Shabtay et al 2008).

This study was aims to evaluate (i) the therapeutic effects of alcoholic, aqueous and oil extracts of rosemary on acute hyperglycemia induced by streptozotocin in male rats. (ii) The protective effects of the previous extracts of rosemary on the liver toxicity induced by $\mathrm{CCl}_{4}$ in male rats. The protective and therapeutic effects of these plant extracts compared to the adverse effects of $\mathrm{CCl}_{4}$ or STZ were determined through different blood biochemical assays.

\section{MATERIALS AND METHODS}

\section{Materials}

\section{Plant material}

Samples of dried Rosemary (Rosmarinus officinalis $\mathrm{L}$.) and rosemary oil were obtained from $\mathrm{Ag}$ ricultural Seeds, Spices and Medicinal Plants Co., Al-Azhar st., Cairo, Egypt.

\section{Reagent kits}

Aspartate aminotransferase (AST), Alanine aminotransferase (ALT), Total protein, Albumin, Glucose, Cholesterol, High density lipoprotein cholesterol (HDL-C), Triglycerides, Alkaline phosphatase (ALP) kits were obtained from Egyptian company for Biotechnology, Obour city Industrial area, block 20008 pieces 19A. Cairo, Egypt.

\section{Methods of analysis}

\section{Preparation of plant extracts}

\section{Ethanolic extract}

Dried rosemary $(100 \mathrm{~g})$ was extracted three times with (400, 300 and $200 \mathrm{ml}$ ) ethanol (95\%) for 24 hours at room temperature $\left(25^{\circ} \mathrm{C}\right)$, and the samples were shaken and filtered after each extraction. Solvent was removed from the combined 
extracts with a vacuum rotary evaporator at $40^{\circ} \mathrm{C}$ to obtain crude plant extracts. The dried extracts were weighed and stored at $-20^{\circ} \mathrm{C}$. Final extract was a dark green powder.

\section{Aqueous extract}

Dried rosemary $(100 \mathrm{~g})$ was extracted three times with $(800,600$ and $400 \mathrm{ml})$ distilled water for 24 hours at room temperature $\left(25^{\circ} \mathrm{C}\right)$, and the samples were shaken and filtered after each extraction. Solvent was removed from the combined extracts with a freezing drying to obtain crude plant extract. The dried extract was weighed and stored at $-20^{\circ} \mathrm{C}$. Final extract was a dark brown powder

\section{GC-MS analysis of rosemary oil}

GC-MS analysis of rosemary oil was carried out in faculty of science, Ain Shams University, Cairo, Egypt.

\section{Biological Experiment}

\section{Experimental animals}

A total of 54 adult male albino rats (weighing 160-200g) were obtained from Agricultural Research Center in Giza, Egypt. The animals were housed in acrylic cages in standard conditions of temperature prior to the experiments for one week in order to adapt to the laboratory condition, and they were also fed with commercial diet and water (Hanan, 2012).

\section{Induction of Experimental Diabetes}

A freshly prepared solution of Streptozotocin (STZ) $(50 \mathrm{mg} / \mathrm{kg}$ body weight in $0.1 \mathrm{M}$ citrate buffer, $\mathrm{pH} 4.5)$ was injected intraperitonially for overnight fasted rats. STZ injected animals exhibited hyperglycemia within 48-36h (Singh et al 2007). The rats having fasting blood glucose (FBG) values of $250 \mathrm{mg} / \mathrm{dl}$ or above were considered for the study.

\section{Protection of Experimental Hepatitis}

A freshly prepared solution of carbon tetrachloride $\left(\mathrm{CCl}_{4}\right)(1 \mathrm{ml} / \mathrm{kg}$ body weight dissolved in corn oil $50 \% \mathrm{v} / \mathrm{v}$ ) was injected intraperitonially twice a week for 21 days for all groups (Heibatollah et al 2008).

\section{Experimental design}

The experiment was carried out on (9) groups of six rats in each group to study the effect of rosemary extracts on diabetic and liver malfunctional rats as follows:

Group 1: Control rats received standard normal diet. The other groups received the different treatments besides being fed on the normal diet. Group 2: Diabetic control rats (rats + STZ). Group 3, STZ induced diabetic rats, was treated with alcoholic extract of Rosemary orally by stomach tube with a dose of $(200 \mathrm{mg} / \mathrm{kg}$ body weight) daily for 3 weeks. Group 4, STZ induced diabetic rats, was treated with aqueous extract of Rosemary orally by stomach tube with a dose of $(200 \mathrm{mg} / \mathrm{kg}$ body weight) daily for 3 weeks. Group 5, STZ induced diabetic rats, was treated with Rosemary essential oil orally by stomach tube with a dose of (200mg/kg body weight) daily for 3 weeks. Group 6: Hepatitis control rats (rats $+\mathrm{CCl}_{4}$ ). Group 7, $\mathrm{CCl}_{4}$ induced hepatotoxicity, was treated with alcohol extract of Rosemary orally by stomach tube with a dose of $(500 \mathrm{mg} / \mathrm{kg}$ body weight) day after day for 3 weeks. Group 8, $\mathrm{CCl}_{4}$ induced hepatotoxicity, was treated with aqueous extract of Rosemary orally by stomach tube with a dose of (250mg/kg body weight) day after day for 3 weeks. Group 9, $\mathrm{CCl}_{4}$ induced hepatotoxicity, was treated with Rosemary essential oil orally by stomach tube with a dose of $(250 \mathrm{mg} / \mathrm{kg}$ body weight) day after day for 3 weeks.

\section{Statistical analysis}

The data were presented as means \pm SD from six replicates and subjected to one way ANOVA. The means of different treatments were compared using Duncan's multiple range tests at $p \leq 0.05$. Statistical analyses were performed using SPSS statistical software (IBM SPSS Statistics, version 20) (Snedecor and Cochran, 1980).

\section{RESULTS AND DISCUSSION}

\section{1- GC-MS analysis of rosemary oil}

GC-MS of rosemary oil is illustrated and calculated in Table (1). The data refer that Rosemary oil contains mainly terpenes. Many of these compounds have antioxidant properties. The results agree with what obtained by (Wang et al 2008). 
Table 1. GC-MS analyses of Rosemary oil

\begin{tabular}{|c|c|l|}
\hline RT & $\begin{array}{c}\text { Area } \\
\text { Pct }\end{array}$ & \multicolumn{1}{|c|}{ Library/ID } \\
\hline 8.81 & 3.01 & p-Cymene \\
8.88 & 2.97 & D-Limonene \\
8.94 & 50.96 & 1,8-Cineole \\
10.13 & 1.03 & Linalool \\
10.87 & 9.32 & (+)-2-Bornanone \\
11.23 & 2.41 & endo-Borneol \\
11.60 & 1.74 & alpha-Terpineol \\
14.84 & 2.32 & caryophylene \\
7.09 & 16.13 & a-pinene \\
7.17 & 0.13 & 1-Methyl-3-piperidinemethanol \\
7.38 & 4.85 & Camphene \\
7.92 & 1.50 & beta-Pinene \\
8.20 & 1.36 & beta-Myrcene \\
8.44 & 0.25 & Bicyclo[3.1.0]hex-2-ene,2-methyl- \\
& & 5-(1-methylethyl) \\
8.66 & 0.56 & cyclohexene,1-methyl-4-(1- \\
& & methylethylidene) \\
\hline
\end{tabular}

2- Therapeutic effect of the extracts of rosemary (alcoholic, aqueous) and its oil on the acute hyperglycemia induced by streptozotocin in rats

Effects of the extracts of rosemary (alcoholic or aqueous) and its oil on the levels of fasting and postprandial blood glucose analyzed at the end of experiment period ( 21 days) in rats treated with streptozotocin are shown in (Tables $2 \& 3$ ). The rats treated with streptozotocin only (positive control) and diabetic rats received alcoholic, aqueous or oil extracts of rosemary recorded high levels of fasting blood glucose $(309.9,311.9,306.5$ and $359.8 \mathrm{mg} / \mathrm{dl}$, respectively) compared to the negative control group $(96.6 \mathrm{mg} / \mathrm{dl})$ at zero time. Similarly the rats treated with streptozotocin (STZ) only (positive control) and diabetic rats received alcoholic, aqueous or oil extracts of rosemary recorded high levels of postprandial blood glucose (440.0, $428.2,457.4$ and $471.3 \mathrm{mg} / \mathrm{dl}$, respectively) compared to the negative control group $(126.4 \mathrm{mg} / \mathrm{dl}$ ) at zero time. There were slight increase in the levels of fasting and postprandial blood glucose for the positive control, and gradual decrease for dia- betic rats treated with alcoholic, aqueous or oil extracts of rosemary during three weeks. The levels of fasting blood glucose of rats induced by STZ and treated by alcoholic, aqueous or oil extracts after 21 days are (144.9, 119.7 and $99.6 \mathrm{mg} / \mathrm{dl}$, respectively). As it is shown from the previous data that the alcoholic extract of rosemary was found to have therapeutic potential. It possesses hypoglycemic properties but the aqueous and oil extracts of rosemary were more efficient, (restoring the levels of fasting and postprandial blood glucose to their normal ranges after 21 days). These data are similar to these obtained by (Bakirel et al 2008).

Diabetic rats showed a significant increase of glucose level associated to a significant decrease of insulin level, in comparison to their respective values in control. STZ leads to diabetes by destroying the insulin secreting cells of the pancreas and correspondingly leads to hypoinsulinemia and hyperglycemia. It means that STZ leads to hyperglycemia by specific cytotoxic impact on pancreatic beta cells. One of the intracellular phenomena for its cytotoxicity is through the production of free radicals exhibited both in-vivo and in-vitro as stated by (Yadav et al 2002).

Table 2. Effect of alcoholic, aqueous or oil extracts of rosemary on the levels of fasting blood glucose $(\mathrm{mg} / \mathrm{dl})$ analyzed weekly in rats treated with (STZ).

\begin{tabular}{|c|c|c|c|c|}
\hline Time & Zero & 7 days & 14 days & 21 days \\
\hline Control & $\begin{array}{l}96.6^{\mathrm{b}} \\
\pm 51.9\end{array}$ & $\begin{array}{l}101.3^{c} \\
\pm 41.3\end{array}$ & $\begin{array}{l}91.7^{d} \\
\pm 36.9\end{array}$ & $\begin{array}{l}103.1^{c} \\
\pm 40.7\end{array}$ \\
\hline STZ only & $\begin{array}{l}309.9^{a} \\
\pm 79.1\end{array}$ & $\begin{array}{l}325.6{ }^{a} \\
\pm 58.6\end{array}$ & $\begin{array}{l}334.3^{a} \\
\pm 47.1\end{array}$ & $\begin{array}{l}347.5^{a} \\
\pm 50.8\end{array}$ \\
\hline STZ + alcoholic & $\begin{array}{l}311.9^{a} \\
\pm 43.5\end{array}$ & $\begin{array}{l}292.7^{a b} \\
\pm 37.9\end{array}$ & $\begin{array}{l}234.9^{\mathrm{b}} \\
\pm 41.4\end{array}$ & $\begin{array}{l}144.9^{\mathrm{b}} \\
\pm 45.9\end{array}$ \\
\hline STZ +Aqueous & $\begin{array}{l}306.5^{\mathrm{a}} \\
\pm 44.3\end{array}$ & $\begin{array}{l}241.9^{b} \\
\pm 39.9\end{array}$ & $\begin{array}{l}177.0^{c} \\
\pm 42.3\end{array}$ & $\begin{array}{l}119.7^{c} \\
\pm 44.5\end{array}$ \\
\hline $\begin{array}{l}\text { STZ + } \\
\text { Oil }\end{array}$ & $\begin{array}{l}359.8^{\mathrm{a}} \\
\pm 41.3\end{array}$ & $\begin{array}{l}288.1^{a b} \\
\pm 41.2\end{array}$ & $\begin{array}{l}212.6^{c} \\
\pm 45.9\end{array}$ & $\begin{array}{l}99.6^{c} \\
\pm 57.2\end{array}$ \\
\hline
\end{tabular}

The data represent the means \pm SE calculated from six replicates. Different letters refer to significant differences at $(P \leq 0.05)$. 
Table 3. Effect of alcoholic, aqueous or oil extracts of rosemary on the levels of postprandial blood glucose $(\mathrm{mg} / \mathrm{dl})$ analyzed weekly in rats treated with (STZ).

\begin{tabular}{|c|c|c|c|c|}
\hline Time & Zero & 7 days & 14 days & 21 days \\
\hline \multirow{2}{*}{ Control } & $126.4^{d}$ & $131.6^{d}$ & $119.6^{d}$ & $135.8^{c}$ \\
\hline & \pm 67.1 & \pm 52.2 & \pm 51.9 & \pm 63.8 \\
\hline \multirow{2}{*}{ STZ only } & $440.0^{c b}$ & $449.5^{a}$ & $465.8^{a}$ & $478.6^{a}$ \\
\hline & \pm 61.2 & \pm 50.7 & \pm 54.3 & \pm 66.6 \\
\hline \multirow{2}{*}{ STZ + alcoholic } & $428.2^{c}$ & $376.2^{b}$ & $282.1^{b}$ & $160.9^{b}$ \\
\hline & \pm 63.2 & \pm 53.1 & \pm 56.9 & \pm 68.7 \\
\hline \multirow{2}{*}{ STZ +Aqueous } & $457.4^{a b}$ & $366.5^{b}$ & $274.4^{b}$ & $140.9^{c}$ \\
\hline & \pm 66.5 & \pm 54.5 & \pm 55.7 & \pm 67.2 \\
\hline $\mathrm{STZ}+$ & $471.3^{a}$ & $322.2^{c}$ & $240.2^{c}$ & $132.2^{c}$ \\
\hline Oil & \pm 69.2 & \pm 60.9 & \pm 63.8 & \pm 75.5 \\
\hline
\end{tabular}

The data represent the means \pm SE calculated from six replicates. Different letters refer to significant differences at $(P \leq 0.05)$.

The mechanism of the anti-diabetic activity indicates that rosemary extracts, especially rosemary oil works as a protection and stimulation of $\beta$ cells of pancreatic islets, since it increases $\beta$-cells and subsequent release of insulin. It also increases insulin receptor. Rosemary extract reduces blood sugar through regeneration $\beta$-cell. It could be said that this extract may have antidiabetic effect by preventing mucosal damage of $\beta$-cells, i.e. preventing of oxidative stress and regenerating of $\beta$ cells. This subsequent improves the increase secretion of insulin from $\beta$-cells of pancreas.

3- Therapeutic effect of alcoholic, aqueous or oil extracts of rosemary plant on Triglycerides (TG), total cholesterol (TC), (HDL) and (LDL)

Low Density Lipoprotein (LDL) is considered as a bad lipoprotein because it transfers cholesterol from liver to tissues, but High Density Lipoprotein (HDL) is considered as a good lipoprotein because it transfers cholesterol from tissues to liver.

The serum lipid parameters, triglycerides, total cholesterol and LDL in the STZ diabetic rats increased, while HDL decreased in comparison with negative control group, since it amounted in rats administrated alcoholic extract or aqueous extract of rosemary (46.1 and $49.8 \mathrm{mg} / \mathrm{dl}$ respectively), i.e. there is a significant difference between these two groups and the control one as it is shown in Table
(4). However the HDL in group administrated rosemary oil is amounted $(55.1 \mathrm{mg} / \mathrm{dl})$ and this amount is significantly higher than both positive control $(42.2 \mathrm{mg} / \mathrm{dl})$ and negative control (51.3 $\mathrm{mg} / \mathrm{dl})$.

\section{4- Protective effect of Rosemary extracts on the liver toxicity induced by $\mathrm{CCl}_{4}$ in rats}

a) Effect of alcoholic, aqueous and oil extracts of rosemary on the liver functions in rats treated with $\mathrm{CCl}_{4}$

The adverse effects of liver toxicity was produced by intraperitonially administration of $\mathrm{CCl}_{4}$ twice a week for 21 days at a dose of $(1 \mathrm{ml} / \mathrm{kg}$ body weight dissolved in corn oil $50 \% \mathrm{v} / \mathrm{v}$ ) for experimental rats. The protective effects of alcoholic, aqueous or oil extracts of rosemary which were administered orally by stomach tube day after day for 21 days at a dose of $(500,250$ and $250 \mathrm{mg} / \mathrm{kg}$ respectively) was noticed. This administration was done to avoid these adverse effects through antioxidant and/or anti-inflammatory activity of extracts of this plant. The protective effects were monitored through activity determination of different liver enzymes namely alanine aminotransferase (ALT), aspartate aminotransferase (AST) and alkaline phosphatase (ALP) in the serum. These results agree with those obtained by (Kaliora and Andrikopoulos, 2005) who mentioned that rosemary extracts are found to exhibit different effects as hepatoprotective and anticancer.

\section{b) Serum alanine aminotransferase (ALT) activ- ity}

The enzymes ALT and AST are widely distributed with high concentration in liver and to a lesser extent in kidneys and heart. Although both serum ALT and AST become elevated whenever disease processes affect liver cell integrity, ALT is the more liver specific enzyme. The ALT and AST are enzymes involved in amino acid metabolism and are used as a marker in liver diseases.

Effect of oral administration of alcoholic, aqueous extracts of Rosemary or its oil on the levels of serum ALT activity analyzed at the end of experiment period in rats treated with $\mathrm{CCl}_{4}$ are shown in Fig. (1). The levels of ALT when alcoholic extract, aqueous extract or oil of rosemary was administrated to rats are $(39.42,30.9$ and $16.42 \mathrm{U} / \mathrm{L}$ respectively). The results revealed that the activity of serum ALT enzyme records high levels (50.9 U/L) 
Table 4. Effect of Rosemary extracts (alcoholic, aqueous or oil) on the levels of serum triglycerides, total cholesterol, HDL and LDL in rats treated with STZ at the end of the experiment

\begin{tabular}{|c|c|c|c|c|c|}
\hline & Control & STZ & STZ+alcoholic & STZ+aqueous & STZ+ oil \\
\hline Triglycerides (mg/dl) & $88.0^{e} \pm 1.6$ & $201.3^{a} \pm 2.7$ & $185.5^{b} \pm 1.1$ & $154.9^{c} \pm 1.3$ & $114.5^{d} \pm 3.1$ \\
\hline Total cholesterol (mg/dl) & $93.1^{\mathrm{e}} \pm 1.4$ & $189.2^{a} \pm 1.2$ & $151.5^{b} \pm 1.3$ & $122.8^{c} \pm 0.5$ & $107.4^{d} \pm 0.8$ \\
\hline HDL (mg/dl) & $51.3^{\mathrm{b}} \pm 0.8$ & $42.2^{d} \pm 1.1$ & $46.1^{c} \pm 0.8$ & $49.8^{b} \pm 0.4$ & $55.1^{a} \pm 0.5$ \\
\hline LDL (mg/dl) & $24.1^{e} \pm 0.3$ & $106.7^{\mathrm{a}} \pm 0.4$ & $68.3^{b} \pm 1.6$ & $42.0^{c} \pm 0.3$ & $29.3^{d} \pm 0.8$ \\
\hline
\end{tabular}

The data represent the means \pm SE calculated from six replicates. Different letters refer to significant differences at $(P \leq 0.05)$.

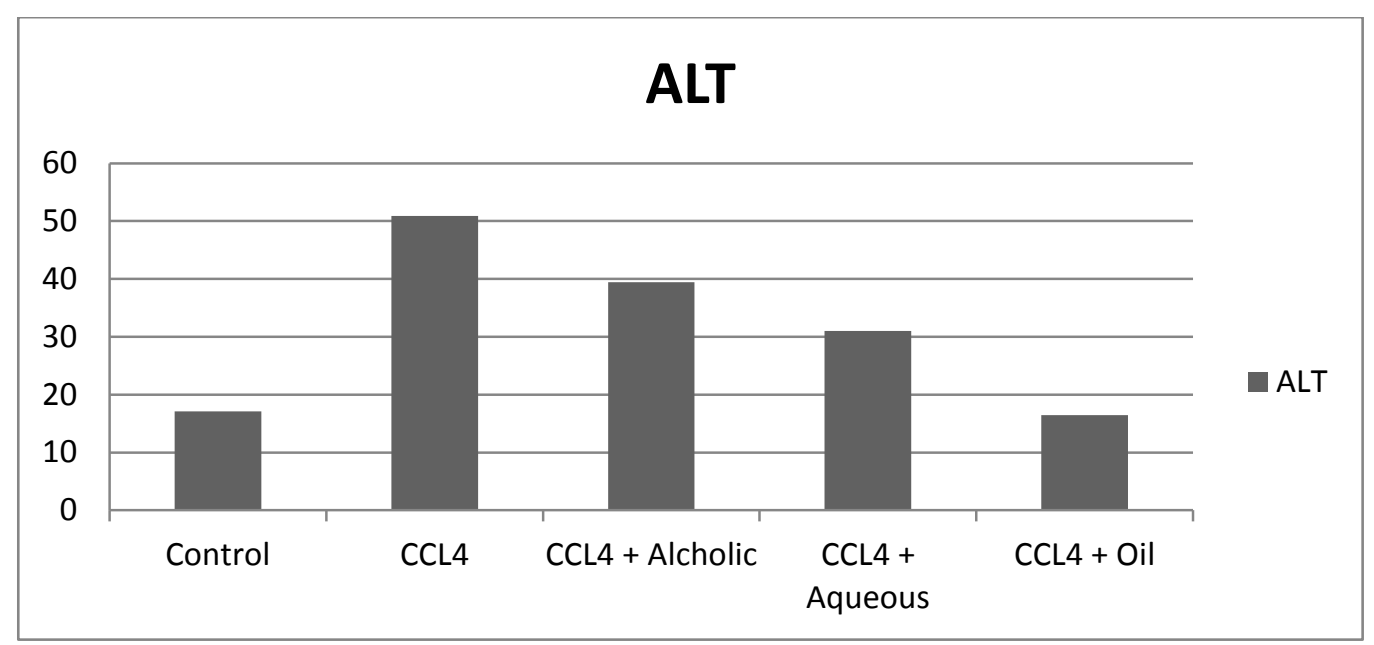

Fig. 1. Effect of Rosemary extracts "alcoholic, aqueous or oil" on the levels of ALT in rats treated with $\mathrm{CCl}_{4}$ after three weeks

for the positive control (The rats treated with $\mathrm{CCl}_{4}$ only) compared to the negative control (17.1 $\mathrm{U} / \mathrm{L})$. There is a significant difference between both negative control (17.1 U/L) and positive control $(50.9 \mathrm{U} / \mathrm{L})$ and the values of $\mathrm{ALT}$ in the rats treated by alcoholic or aqueous extracts of rosemary. The protective effects of the plant extracts against liver toxicant occurred by decreasing the activities of this enzyme.

\section{c) Serum aspartate aminotransferase (AST) activity}

The activity of AST in rats administrated by $\mathrm{CCl}_{4}+$ alcoholic extract, $\mathrm{CCl}_{4}+$ aqueous extract and $\mathrm{CCl}_{4}+$ rosemary oil were $(49.42,41.43$ and $26.1 \mathrm{U} / \mathrm{L}$ respectively) as it shown in Fig. (2). The data indicated that the activity of serum AST enzyme reached high levels (59.5 U/L) for the positive control (in rats treated with $\mathrm{CCl}_{4}$ only) compared to the negative control $(29.1 \mathrm{U} / \mathrm{L})$. The difference between both negative control $(29.1 \mathrm{U} / \mathrm{L})$ and positive control (59.5 U/L) and the activity of AST in the rats treated by alcoholic and aqueous extracts of rosemary is significant. The protective effects of the plant extracts against liver toxicant occurred by decreasing the activities of this enzyme. 


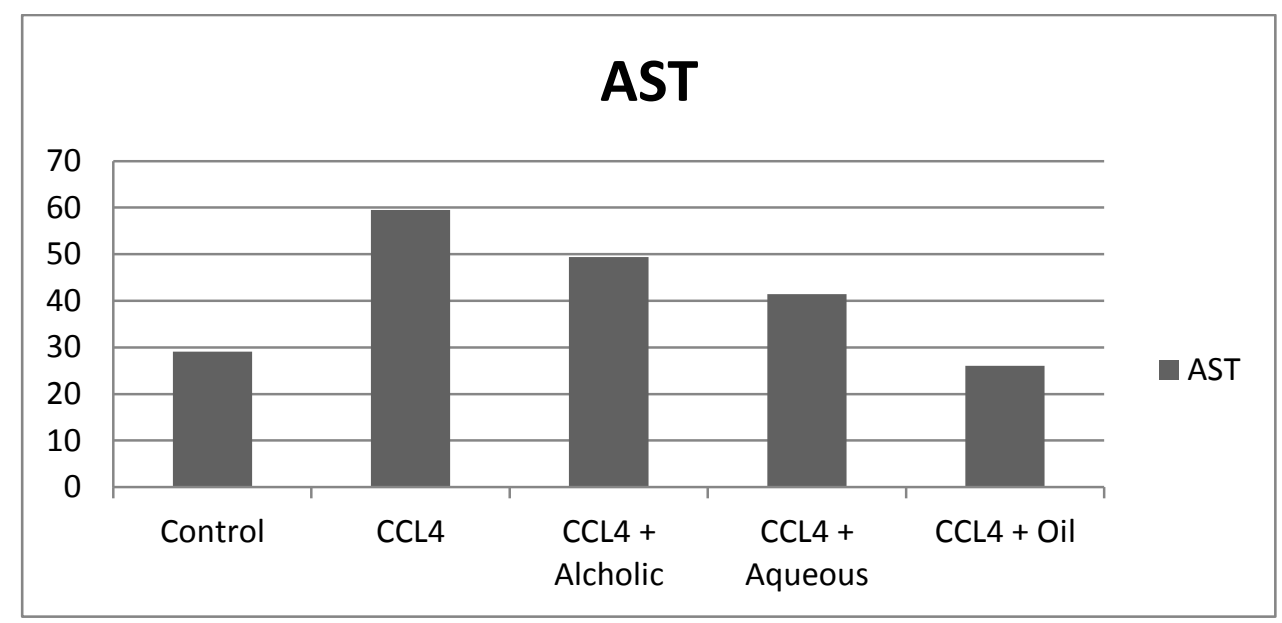

Fig. 2. Effect of Rosemary extracts "alcoholic, aqueous or oil" on the levels of AST in rats treated with $\mathrm{CCl}_{4}$ after three weeks.

\section{d) Serum alkaline phosphatase (ALP) activity}

ALP is an enzyme in the cells lining the biliary duct of the liver. ALP levels in plasma rise with large bile duct obstruction, intrahepatic cholestasis, or infiltrative diseases of the liver. Biliary tract disease produces relatively greater increases in ALP than increases in ALT, AST. ALP is associated with the plasma membrane of hepatocytes adjacent to the biliary canaliculus.

Effect of oral administration of alcoholic, aqueous and oil extracts of rosemary on the levels of serum ALP activity analyzed at the end of experiment period in rats treated with $\mathrm{CCl}_{4}$ are shown in Fig. (3). The activity of ALP were (131.2, 102.8 and $70.8 \mathrm{U} / \mathrm{L}$ respectively) in administrating rats with alcoholic, aqueous and oil extracts. The results revealed that the activity of serum ALP enzyme reached high levels (136.5 U/L) for the positive control (in rats treated with $\mathrm{CCl}_{4}$ only) compared to the negative control $(71.3 \mathrm{U} / \mathrm{L})$.

The activity of serum ALT, AST and ALP are significantly increased due to the administration of $\mathrm{CCl}_{4}$, which supports the finding that the liver is necrotized; therefore the increase of the liver enzymes activity in serum is mainly due to the leakage of these enzymes from the liver into blood stream, as mentioned by (Mansour et al 2002).

\section{e) Serum proteins}

The mean values of serum total proteins and albumin of $\mathrm{CCl}_{4}$ induced rats are tabulated in Table (5). The data did not show any significant dif- ferences in the level of serum total proteins and albumin for rats treated with alcoholic extract, aqueous extract or oil of rosemary compared to the positive control group ( $\mathrm{CCl}_{4}$ only).

\section{f) Serum triglycerides}

Triglycerides are the main lipids present in the human plasma; the others are the cholesterol, phospholipids and nonesterified fatty acids. The measurements of serum triglycerides are important in the diagnosis of hyperlipoproteinemia, liver obstruction and other diseases involving lipid metabolism. In the human body, high levels of triglycerides in the blood stream have been linked to atherosclerosis and by extension, the risk of heart disease and stroke (Yasim et al 2011).

Effects of oral administration of alcoholic, aqueous or oil extracts of rosemary on the levels of serum triglycerides analyzed at the end of experiment period in rats treated with $\mathrm{CCl}_{4}$ are (144.3, 123.3 and $90.8 \mathrm{mg} / \mathrm{dl}$ respectively) as it is shown in Table (6). The results revealed that the levels of serum triglycerides reached high levels (338.6 $\mathrm{mg} / \mathrm{dl}$ ) for the positive control (in rats treated with $\mathrm{CCl}_{4}$ only) compared to the negative control (110.1 $\mathrm{mg} / \mathrm{dl})$. There were no significant $(\mathrm{p} \leq 0.05)$ differences in the levels of serum triglycerides for the rats received the plant extracts compared to the negative control. The protective effects of the plant extracts (alcoholic, aqueous or oil) against the liver toxicant $\left(\mathrm{CCl}_{4}\right)$ occurred through appearance of this parameter levels in their normal ranges. 


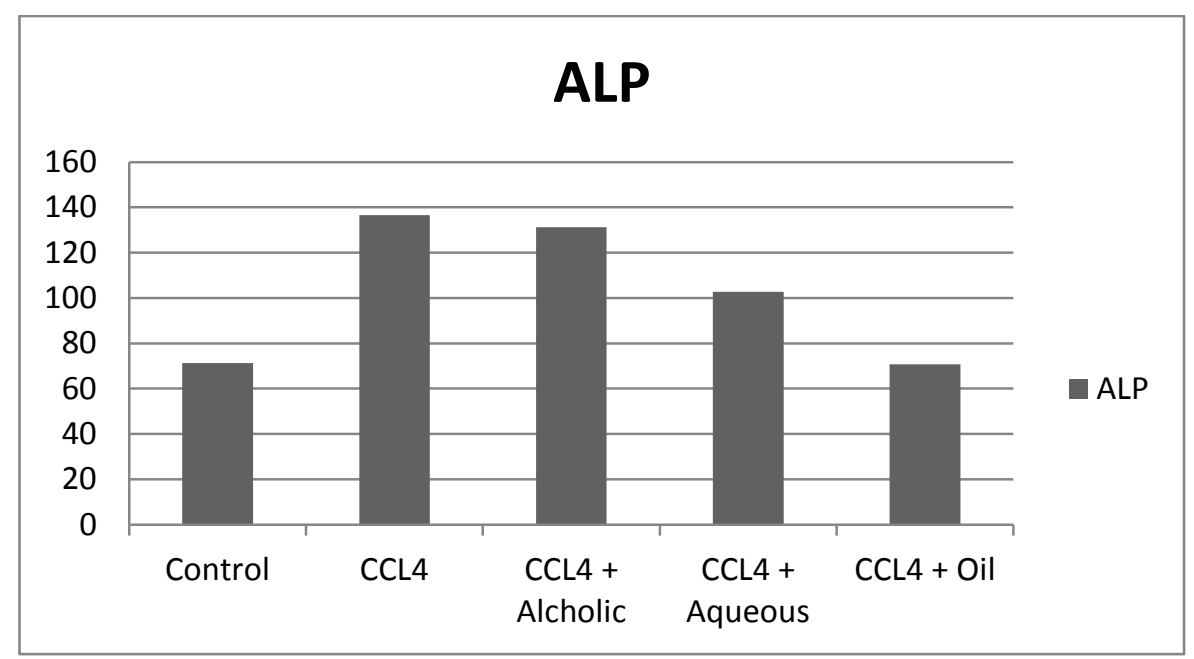

Fig. 3. Effect of Rosemary extracts "alcoholic, aqueous or oil" on the levels of ALP in rats treated with $\mathrm{CCl}_{4}$ after three weeks

Table 5. Effect of Rosemary extracts "alcoholic, aqueous or oil" on the levels of total proteins, albumin in rats treated with $\mathrm{CCl}_{4}$ at the end of the experiment.

\begin{tabular}{|l|c|c|c|c|c|}
\hline & Control & $\mathrm{CCl}_{4}$ & $\begin{array}{c}\mathrm{CCl}_{4} \\
\text { alcoholic }\end{array}$ & $\begin{array}{c}\mathrm{CCl}_{4+} \\
\text { aqueous }\end{array}$ & $\mathrm{CCl}_{4}+$ oil \\
\hline $\begin{array}{l}\text { Total proteins } \\
\text { (g/dl) } \\
\begin{array}{l}\text { Albumin } \\
\text { (g/dl) }\end{array}\end{array}$ & $6.53^{\mathrm{a}} \pm 0.75$ & $7.41^{\mathrm{a}} \pm 0.28$ & $6.37^{\mathrm{a}} \pm 0.68$ & $6.83^{\mathrm{a}} \pm 0.08$ & $7.20^{\mathrm{a}} \pm 0.56$ \\
\hline
\end{tabular}

The data are presented as means \pm SD from six replicates. Different letters refer to significant differences at $(P \leq 0.05)$.

Table 6. Effect of Rosemary extracts (alcoholic, aqueous or oil) on the level of serum triglycerides, total cholesterol, $\mathrm{HDL}$ and $\mathrm{LDL}$ in rats treated with $\mathrm{CCl}_{4}$ at the end of the experiment

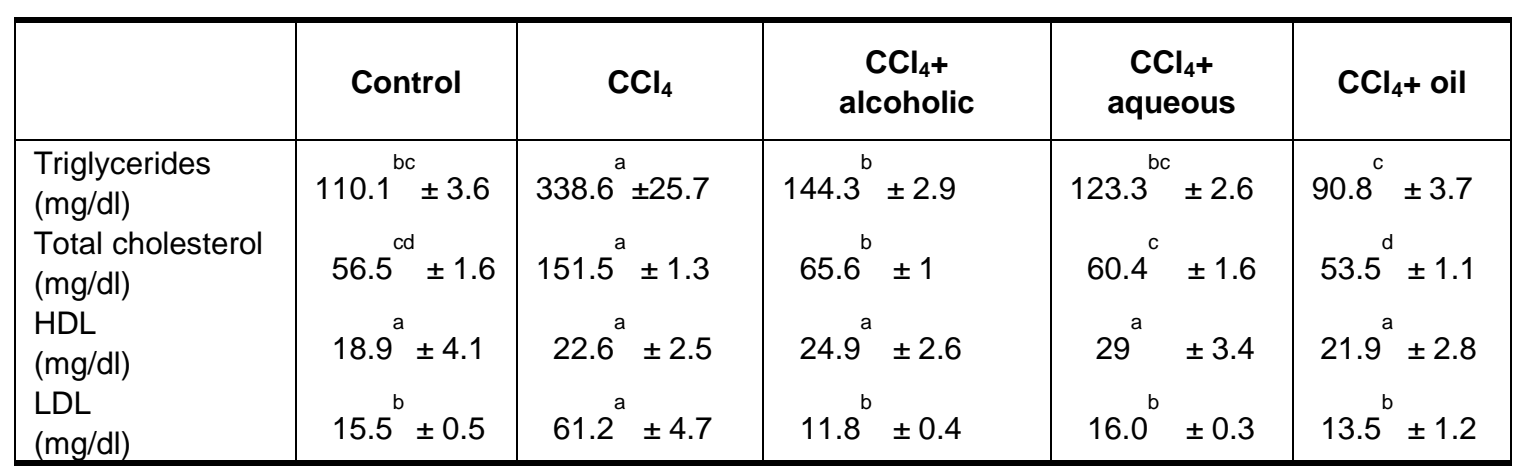

The data are presented as means \pm SD from six replicates. Different letters refer to significant differences at $(P \leq 0.05)$. 
g) Serum total cholesterol and cholesterol fractions

Effects of oral administration of alcoholic, aqueous or oil extracts of rosemary on the levels of serum total cholesterol analyzed at the end of experiment period in rats treated with $\mathrm{CCl}_{4}$ are shown in Table (6). The results revealed that the levels of serum total cholesterol recorded high levels (151.5 $\mathrm{mg} / \mathrm{dl}$ ) for the positive controls (in rats treated with $\mathrm{CCl}_{4}$ only) compared to the negative control (56.5 $\mathrm{mg} / \mathrm{dl})$. The protective effects of the plant extracts against liver toxicant occurred by decreasing the levels of serum total cholesterol and there were no significant ( $p \leq 0.05)$ differences in the levels of serum total cholesterol for the rats received the plant extracts (aqueous and oil) compared to the negative control.

Table (6) reveals the effect of alcoholic, aqueous extracts or oil of rosemary on the levels of serum $\mathrm{HDL}$ and $\mathrm{LDL}$ in rats treated with $\mathrm{CCl}_{4}$. The amounts of HDL of rats treated by alcoholic, aqueous or oil extracts of rosemary are $(24.9,29$ and $21.9 \mathrm{mg} / \mathrm{dl}$ respectively). There were no significant $(p \leq 0.05)$ differences in the levels of serum HDLcholesterol for all treatments compared to the negative and positive controls.

The data illustrated that the levels of serum LDL recorded high levels $(61.2 \mathrm{mg} / \mathrm{dl})$ for the positive controls compared to the negative control $(15.5 \mathrm{mg} / \mathrm{dl})$. There are no significant $(p \leq 0.05)$ differences in the levels of serum LDL for the rats received the plant extracts (alcoholic, aqueous) or oil compared to the negative control. The protective effects of both plant extracts against liver toxicant occurred through appearance of this parameter levels in their normal values.

\section{REFERENCES}

Aruoma, O.I., Halliwell, B., Aeschbach, R. and Loligers, J., 1992. Antioxidant and pro-oxidant properties of active rosemary constituents: carnosol and carnosic acid. Xenobiotica, 22, 257268.

Bakirel T., Bakirel, U., Keles, O.U., Ulgen, S.G. and Yardibi, H. 2008. In vivo assessment of antidiabetic and antioxidant activities of rosemary (Rosmarinus officinalis) in alloxandiabetic rabbits. J. of Ethnopharmacology, 116, 64-73.

Begum, A., Sandhya, S., Syed Shaffath, A., Vinod, K.R., Swapna, R. and Banji, D. 2013.
An in-depth review on the medicinal flora Rosmarinus officinalis (Lamiaceae). Acta Sci. Pol., Technol. Aliment, 12(1), 61-73.

Domokos, J., Hethelyi, E., Palinkas, J., Szirmai S. and Tulok M.H. 1997. Essential oil of rosemary (Rosmarinus officinalis L.) of Hungarian origin. J. Essent. Oil Res, 9, 41-45.

Dubois, M., Bailly, F., Mbemba, G., Mouscadet, J.F., Debyser, Z., Witvroun, M. and Cotelle, P. 2008. Reaction of Rosmarinic Acid with Nitrite lons in Acidic Conditions: Discovery of $\mathrm{Ni}$ tro- and Dinitrorosmarinic Acids as New AntiHIV-1 Agents. J. Med. Chem., 51, 2575-2579.

El-Deeb, K.S. 1993. Investigation of Tannin in Some Labiatae Species. Bulletin of Faculty of Pharmacy, 31, 237-241.

El-Hilaly, J., Adil, T., Zafar, H.I. and Badiâa, L.A. 2007. Hypoglycemic,Hypocholesterolemic and Hypotriglyceridemic effects of continuous intravenous infusion of a lyophilized aqueous extract of Ajuga iva I. Schreber whole plant in streptozotocin-Induced diabetic rats. Pakistan J. of Pharmaceutical Sci., 20, 261-268.

Faixova, Z. and Faix, S. 2008. Biological effects of Rosemary (Rosmarinus officinalis L.) essential oil (A Review), Folia Veterinaria, 52(3-4), 135139.

Fuhrman B., Volkova, N., Rosenblat, M. and Aviram, M. 2000. Lycopene Synergistically Inhibits LDL Oxidation in Combination with Vitamin E, Glabridin, Rosmarinic acid, Carnosic acid or Garlic. Antioxid. Redox. Signal, 2, 491506.

Furtado, R.A., Rezende de Araujo, F.R., Resende, F.A., Cunha, W.R. and Tavares, D.C. 2010. Protective effect of rosmarinic acid on V79 cells evaluated by the micronucleus and comet assays. J. Appl. Toxicol, 30, 254259.

Hadafi, A., Ismaili Alaoui, M., Chaouch, A., Benjilali, B. and Zrira, S. 1998. Antioxidant activity and phenolic acid content in rosemary (Rosmarinus officinalis L.) and myrtle (Myrtus Communis). Riv. Ital, pp. 325-340.

Hanan, S.A. 2012. Effect of Rosmarinus Officinalis Extract on some Cardiac Enzymes of Streptozotocin-induced Diabetic Rats. J. of Health Sci., 2(4), 33-37.

Heibatollah, S., Nikbakht, R.M. Ghaitasi, I. and Sabzali, S. 2008. Hepatoprotective effect of Cichorium intybus on $\mathrm{CCl}_{4}$-induced liver damage in rats. African J. of Biochemistry Research, 2(6), 141-144. 
Herrero, M., Plaza, M., Cifuentes, A. and Ibanez, E. 2010. Green Processes for the Extraction of Bioactives from Rosemary: Chemical and Functional Characterization via UltraPerformance Liquid Chromatography-Tandem Mass Spectrometry and in-Vitro Assays. J. of Chromatography, 1217(16), 2512-2520.

Kaliora, A.C. and Andrikopoulos, N.K. 2005. Effect of Alkanna albugam root on LDL oxidation. A comparative study with species of the Lamiaceae family. Phytotherapy Research, 19, 1077-1079.

Labban, L., Mustafa, U. and Ibrahim, Y.M. 2014. The effects of rosemary (Rosmarinus officinalis) leaves powder on glucose level, lipid profile and lipid perodoxation. Int. J. Clinic. Med., 5, 297-304.

Mackness, M.I., Arrol, S., Abbott, C. and Durrington, P.N. 1993. Protection of low-density lipoprotein against oxidative modification by high-density lipoprotein associated Paraoxonase. Atherosclerosis, 104, 129-135.

Mansour, H.A., Newairy, A.S.A., Yousef, M.I. and Sheweita, S.A. 2002. Biochemical study on the effect of some Egyptian herbs in alloxan induced diabetic rats. Toxic, pp. 170-221.

Moon, D.O., Kim, M.O., Lee, J.D., Choi, Y.H. and Kim, G.Y. 2010. Rosmarinic acid sensitizes cell death through suppression of TNF-alpha induced NF_KB activation and ROS generation in human leukemia U937 cells. Cancer let, 288, 183-191.

Nofer, J.R., Kehrel, B., Fobker, M., Levkau, B., Assmann, G. and Von Eckardstein, A. 2002. HDL and arteriosclerosis: beyond reverse cholesterol transport. Atherosclerosis, 161, 1-16.

Park, S.U., Uddin, M.R., Xu, H., Kim, Y.K. and Lee, S.Y. 2008. Biotechnological applications for rosmarinic acid production in plant. Afr. J. Biotechnol., 7, 4959-4965.

Rababah, T.M., Hettiarachchy, N.S. and Horax, R. 2004. Total Phenolics and Antioxidant Activities of Fenugreek, Green tea, Black tea, Grape seed, Ginger, Rosemary, Gotu kola, and Ginkgo extracts, Vitamin E, and Tertbutylhydroquinone. J. Agric. Food Chem., 52, 5183-5186.
Salido, S., Altarejos, J., Nogueras, M., Sanchez A. and Lugue P. 2003. Chemical composition and seasonal variations of rosemary oil from southern Spain. J. Essen. Oil Res., 15, 10-14.

Shabtay, A., Sharabani, H., Barvish, Z., Kafka, M., Amichay, D., Levy, J., Sharoni, Y., Uskokovic, M.R., Studzinski, G.P. and Danilenko, M. 2008. Synergistic antileukemic activity of carnosic acid-rich rosemary extract and the 19nor Gemini vitamin D analogue in a mouse model of systemic acute myeloid leukemia. Oncology, 75, 203-214.

Shetty, K. 2007. Rosmarinic acid biosynthesis and mechanism of action. Funct. Foods Biotechnol., 187-207.

Singh, S.K., Kesari, A.N., Gupta, R.K., Jaiswal D. and Watal, G. 2007. Assessment of antidiabetic potential of Cynodondactylon extract in streptozotocin diabetic rats. J. of Ethnopharmacology, 114, 174-179.

Snedecor, G.M. and Cochran, W.G. 1980. Statistical methods, Sixth Edition, lowa State Univ. press, Amer. lowa, USA.

Vanithadevi, B. and Anuradha, C.V. 2008. Effect of Rosmarinic Acid on Insulin Sensitivity, Glyoxalase System and Oxidative Events in Liver of Fructose-Fed Mice. Int. J. of Diabetes and Metabolism, 16, 35-44.

Wang, H., Provan, G.J. and Helliwell, K. 2004. Determination of rosmarinic acid and caffeic acid in aromatic herbs by HPLC. Food Chem., 87, 307-311.

Wang, W., Wu N., Zu, Y.G. and Fu, Y.J. 2008. Antioxidative Activity of Rosmarinus officinalis L. Essential Oil Compared to Its Main Components. Food Chemistry, 108, 1019-1022.

Yadav, S., Vats, V., Dhunno, Y. and Grover, J.K. 2002. Hypoglycemic and antihyperglycemic activity of Murraya Koenigii leaves in diabetic rats. J. of Ethno Pharmacology, 82(2-3), 111-116.

Yasim, A., Ozbag D., Kilinc M., Ciralik, H. and Toru, I. 2011. The effect of diosmin-hesperidin combination treatment on the lipid profile and oxidative-antioxidative system in highcholesterol diet-fed rats. Turkish J. of Thoracic and Cardiovascular Sugery, 19(1), 55-61. 